\title{
The Government's Refugee Determination Proposals: An Update
}

\author{
by Tom Clark
}

The government announced proposals for a new procedure for determining refugee status in Canada on May 21, 1986, just days before the May meeting of the Standing Conference of Canadian Organizations working for Refugees.

At the Standing Conference we began to understand the concerns of government officials, but we could not accept the proposals. The Inter-Church Committee for Refugees (ICCR) members subsequently prepared an analysis of their concerns and objections. The government had produced proposals which conflicted with the right to a fair hearing granted under our Charter of Rights and Freedoms. That right was supported by Parliament's Standing Committee on Labour, Employment and Immigration. Missing was the usual appeal to a competent specialized body.

Some argue that there was an error of judgement. The government was put under a time constraint by then Employment and Immigration Minister, Flora MacDonald. Eyeing the problems of overloaded asylum procedures in Europe, and fearing problems here, the government proposed adoption of the same measures considered by European governments for a different set of circumstances and particular problems.

Yet "this rationale ignores that denying some groups access to a fair hearing would not have curbed the large-scale arrival of those refugee claimants from Portugal. Indeed, it limits government freedom of action to write responses to hypothetical situations into legislation. Decisive administrative action must be fashioned for specific problems, if they arise. Still, it is plausible that the measures restricting access were an attempt to reassure claimants in the face of the inevitable uncertainties.

Other NGO groups have suggested that the proposals were deliberately unsatisfactory in order to provoke further debate and further delays, arguing that there are certain advantages to delay. The time required for the present procedure has left claimants in uncertainty for years. Although most critics argue that this delay attracted abuse, proponents counter that it was supposed to serve as a deterrent. The interim procedure announced on May 21st preserves the uncertainty. It grants Minister's Permits, valid for only a year, to persons from countries with severe human rights problems. The right to a fair hearing is replaced by administrative discretion.

However, the deliberate delay theory is too exnical. The absence of an appeal in the government's proposals may rather be a deliberate if over-zealous attempt to speed up the new determination procedure. Yet this hypothesis fails to take into account the fact that administrative discretion has its pitfalls The reaction to the granting of Minister's Permits to 155 Tamils makes this point. Some Canadians who were confused by the govemment's response would probably have been reassured if a competent independent refugee body had undertaken a case by case review of the need for protection. The lies and inconsistencies which upset some Canadians would have been less likely in the nonthreatening, non-adversarial confines of a respected independent determination body.

Altemately, a fear of abuse seems to be the reason why the government tried to speed up the procedure by not providing a meaningful appeal. In similar areas of Canadian law it is usual to find appeal to a specialized competent appeal body with a final level of appeal to the Federal Court. This important safeguard for a refugee, need not add significantly to the time required for an overall refugee determination procedure. A specialized appeal procedure could be tailored to ensure faimess and efficiency in processing refugee appeals and it would allow the Federal Court to play its normal role as watchdog for gross deviations in matters of law.

All these preoccupations of government, however, fail to consider the needs and the rights of the refugee. The refugee claiming status in Canada should have the right to have his or her case heard before a specialized independent decision-making body in a reasonable time. We remain convinced that government concerns of potential abuse and the refugee's need to begin a new life in a safe place point to the same solution. It is a fair and expeditious procedure for all claimants with decisive administrative responses tailored to specific abusive situations if these should arise. Within this expeditious procedure it is feasible to provide a refugee with the additional safeguards of appeal to a specialized appeal body on the merits of the case.

The present government has good fortune in an opportunity to make its mark on Canadian history. It could create refugee-related legislation which Canadians will look back on with pride. It could reinforce the humanitarian tradition for which Canada is increasingly recognized internationally. That is on why September 10th, church leaders requested a meeting on refugee determination with Prime Minister Mulroney.

Tom Clark is the Co-ordinator of the InterChurch Committee for Refugees.

\section{New Publications}

- The International Migration Review has published a Special Double Issue titled "Refugees: Issues and Directions". The main topics are Refugee Movements, Asylum and Protection, Refugee Issues in Developing Countries, and Adjustment and Resettlement (Center for Migration Studies, 209 Flagg Place, Staten Island, New York, NY 10304, USA).

- The Hmong in Transition, edited by Glenn Hendricks, Bruce T. Downing, Amos S. Deinard (Staten Island, New York: Center for Migration Studies, 1986). Thirty leading experts address the effects of mass migration on the Hmong in France, Australia, Thailand and the USA.

- Working with Refugees, edited by Peter I. Rose (Staten Island, New York: Center for Migration Studies, 1986). The edited proceedings of the Simon Shargo conference on refugee resetlement.

- Guide to the Multilanguage Collections in the Public Library Systems of Metropolitan Toronto. The 1986 edition is available to the public free of charge from their local public library branch in the Metropolitan Toronto area. 


\section{ICCR Protests Access Restrictions}

ICCR representatives were in Ottawa on May 21 , 1986 to hear the government propose the new procedure for determining refugee status and for dealing with the backlog of refugee claims.

Although the announcement of an administrative review will excite many claimants in the 20,000 backlog, the criteria for the review are not yet available and so the ICCR cannot comment on the administrative review at this time.

The proposals for refugee determination have some positive elements but, in spite of ten years of advocacy, still contain measures which erode refugee rights by preventing some claimants from having their case heard by the determination body. The ICCR, with other non-governmental organizations, protested these restrictions in its response to the proposals at a press conference.

On February 5, 1986, leaders of nine Canadian churches and religious bodies had delivered a jointly signed leter to Prime Minister Brian Mulroney secking assurance that the new guidelines would not limit the right to a full and fair hearing of a refugee claim in Canada (See ICCR Bulletin, Special Issue February 1986). Many individuals and church-related groups had sent similar letters in support of the church leaders. The new proposals ignore this strong consensus.

\section{Short Analysis of the Proposals}

The proposed streamlined procedure had three elements: access, or who gets to be heard; determination, or how the case is decided; appeal, or review for possible error. While the new determination procedure contains some welcome improvements, questions of access and appeal would breach the fundamental human rights granted under Section 7 of the Canadian Charter of Rights and Freedoms to all people physically in Canada. No provision is made at the end of the process for a meaningful appeal following a negative decision.

\section{a) Laudable Elements of the Proposals}

1. Oral Hearing: The proposals entrench the right to an oral hearing for each refugee case granted access.

2. More than One Decision-Maker: The decisionmaking body consists of two people. Only one vote is necessary for a claim to be successful so the benefit of any doubt will go to the claimant.

3. Separation between Immigration and Refugee Boards: The decision-making body is separate from immigration procedures and will be directly responsible to the Minister of State for Immigration. However, administrative ties may limit the degree of separation. A research centre will be set up with current information on refugee-producing situations. The Minister's discretion to land refugee claimants under exceptional circumstances is protected.

4. Non-Adversarial Hearing: The oral hearing is to be conducted non-adversarially, thus providing a "helpful" environment conducive to eliciting the facts of the case to be presented.

\section{b) Problems with the Proposals Limiting Access}

Four specific groups are denied access to the determination process in the proposals:

1. Refugees with Status from a Signatory Country: These must have documents to prove the right to residency there. The Minister subsequently stated publicly that this will apply to people with "durable protection".

\section{Persons in Canada for 6 Months withou Asking for Status}

\section{Thase returning to Make a Repeat Claim}

\section{People with Removal Orders from Canada}

Decisions of immigration officials who deny access will be reviewable by the Federal Court to ensure they are supported by the evidence.

The restrictions on access are justified by the govemment as a way of preventing anticipated abuse.

\section{Our General Principles:}

The lack of universal access to a fair hearing is a denial of human rights granted under the Canadian Charter of Rights and Freedoms. Denying this right to applicants conflicts directly with the Supreme Coun of Canada decision of April 4, 1985 on the case of Singh et al, which granted an oral hearing to every claimant in Canada. As Judge Wilson noted in the decision: "certainly the guarantees of the Charter would be illusory if they could be ignored because it was administratively convenient to do so" (page 64).

The guidelines for refugee determination, accepted by Canada as part of the 1977 Conclusions of the Executive Committee of the United Nations High Commissioner for Refugees, require that all cases be referred to the refugee determination authority. For immigration officials to control access to this authority is, therefore, unacceptable. The application of such restrictions to access is new and dangerous because it would set a precedent.

\section{Our Specific Objections:}

For each group with restricted access we can foresee circumstances where life, liberty or security of person could be at risk. These persons, therefore, have the right to procedures consistent with the fundamental principles of justice.

The ICCR has consistently argued that the just and expeditious refugee determination procedure which it has advocated would not attract abuse.

The proposed restriction of access for some with prior protection as refugees in another country sets a dangerous precedent because other related exclusions could follow. The proposed restriction goes beyond the exclusions set out in the Geneva Convention and Protocol. Canada supported the Conclusions of the Executive Committee of the United Nations High Commissioner for Refugees, 1979, which require
Canada to consider a request for asylum where physical safety or freedom are endangered in the present asylum country. Within the same spirit, under Canadian law, a Convention refugee has the right not to "be removed from Canada to a country where his life or freedom would be threatened" (Immigration Act, Clause 55).

The proposed appeal of the access restriction to the Federal Court is inadequate. An evaluation of a claimant's protection or of changed circumstances and their impact on a claimant is outside the jurisdiction of the Federal Court because it is not a matter of law, and should be decided by a body well versed in current refugee cases.

\section{c) Problems with the Proposed Appeal}

If a refugee claim has been denied by the refugee determination body, leave to "appeal" to the Federal Court is provided in the proposals.

\section{Our Objections:}

The guidelines for refugee determination, accepted by Canada as part of the 1977 Conclusions of the Executive Committee of the United Nations High Commissioner for Refugees, provide for an appeal.

Such an appeal is normally provided throughout the Canadian judicial system. It is particularly important when life, liberty and security of person are at stake.

Any meaningful appeal must be able to review the merits of the case credibility and facts. Leaves to appeal are only granted when there are flagrant legal violations. In that rare event, the Federal Court does not have the expertise to deal with the facts or the credibility of a refugee claim; it can only make decisions on matters of law.

\section{d) Humanitarian Procedures Unclear}

Many groups of refugees flee serious civil upheaval or strife. Although individuals in these groups may not meet the strict definition of Convention refugee. the United Nations High Commissioner for Refugees asks that such refugees not be sent back to unsafe places. An example would be sending Iranians back to Iran.

The provisions for such humanitarian cases in the new government proposals are unclear. It will be important to ensure a fair and effective procedure:

Entry to the procedure for humanitarian review must not preclude an application for Convention Refugee status.

An independent credible body with expertise comparable with that required for refugee determination procedures should control who is allowed to stay on humanitarian grounds.

Those who are allowed to stay in Canada should be allowed to proceed to permanent residence status. 